\title{
Analysis of Pogogan Jaranan Arts as a Efforts to Improve the Tourism Industry in Nganjuk District: "Content Analysis".
}

\author{
Yunanto Tri Laksono ${ }^{1}$, Ardian Jaya Prasetya ${ }^{2}$, Dhika Yuan Yurisma ${ }^{3}$ \\ ${ }^{I}$ School of Film and Television, Dinamika University of Technology \& Information, Surabaya 60298, East Java, Indonesia \\ ${ }^{2}$ School of Visual Communication Design, Dinamika University of Technology \& Information, Surabaya 60298, East Java, \\ Indonesia \\ ${ }^{3}$ School of Visual Communication Design, Dinamika University of Technology \& Information, Surabaya 60298, East Java, \\ Indonesia \\ *Corresponding author. Email: yunanto@dinamika.ac.edu.
}

\begin{abstract}
Jaranan Pogogan is a cultural manifestation that can increase the role and economic development of the community based on traditional arts tourism, especially in Nganjuk Regency, East Java. The role of the Ministry of Tourism and Creative Economy (Kemenparekraf) in efforts to improve the quality and quality of tourism is also able to be used as a medium in developing the results of regional tourism, especially in Nganjuk Regency. The lack of marketing makes art jaranan pogogan not become destinations visit major tourist in East Java, as efforts to develop the tourism sector. Visit the concept of branding by integrating safety, cleanliness, and health tailored to health protocol in a future pandemic is expected to make more value in increasing traffic domestic tourists and international. In this study the model used is causal, by applying a system of describing and discovering cause and effect relationships, so the existence of a strong correlation is expected to be able to determine the marketing performance strategy, by taking primary data (questionnaires) and also data from the percentage of tourist arrivals. Through the form of segmentation, targeting, marketing mix and sales of the image of the Pogogan network art can be a supporting sector of tourism, especially in Nganjuk Regency. This is what can mediate the relationship between the arts-based tourism sector with tourists, automatically having implications for increasing the income of the economic sector of society.
\end{abstract}

Keywords: Performance Arts, Jaranan Pogogan, Branding Visit, Content Analysis, Tourism.

\section{INTRODUCTION}

Art is a cultural manifestation that grows and develops and has a strong image associated with the form, meaning, and function in society. Traditional performing arts is one of the arts that have a major role in economic development through the tourism sector if managed properly related to cultural preservation. Nganjuk Regency East Java Province is one of the districts that has a lot of art inventory, one of which is the pogogan network, this network is the original network of the East Java people, especially in Nganjuk Regency. Cultural dynamics in the form of cultural events and percent of objects, sites, and areas of performing arts festivals are echoed by many regions in Indonesia, especially East Java. Various efforts have been made by the local government, one of which is based on the Decree of the Head of the Culture and Tourism Office of the Nganjuk Regency Number: 900/62/411,206/2015 concerning the Main 


\section{Procedia Business and Financial Technology}

Proceedings of the 2nd International Conference on Business and M anagement of T echnology (ICO N BM T 2020) - Part 2

Performance Indicators (KPI) of the Nganjuk Regency Culture and Tourism Office. The first targetis "Maintaining local arts and cultural events", with Performance Indicators for the holding of regional arts and cultural heritage preserved and the second target is "Increasing the number of tourist visits", with Performance Indicators tourist visits and the increasing number of PAD from the tourism sector [1] .One of the aims of holding cultural preservation is also to revitalize culture (strengthening). There are 3 (three) steps in revitalizing culture, namely: 1). Understanding to bring awareness, 2). Collective planning, 3). Creative awakening [2]. The role of art jaranan pogogan a positive influence on the culture, because through art jaranan pogogan can reduce Indicators Unemployment rate (unemployment rate), but it takes also a role in the governance of the management carried out by stakeholders (stakeholders), both from the government and local communities. Achieving the goals and mission of tourism development that is good, sustainable (sustainable tourism) and environmentally sound will only be carried out when the achievement process can be done through good tourism governance (good tourism governance) [3].

Tourism -based culture is a sector supporting economic development in Indonesia, also became surgeon tourism industry in the region, and tourism also has great potential if it is offset by a major contribution both by society and government institutions. The factors underlying the economic development through arts-based tourism are regional and international tourist visits, the Central Statistics Agency (BPS) data explains, that tourist arrivals in January and July reached $4,764,864$ people, up $1.83 \%$ compared to the previous year in $20157,903,498$ with growth of $0.06 \%$ [4]. This indicates that the role of traditional performing arts jaranan pogogan in Nganjuk Regency can also participate in the stretching of economic development through arts-based tourism.

But this is inseparable from some of the problems that arise include 1). The development of popular culture or arts, 2). More and more entertainment through television and video, 3). Performing arts cannot adapt to modern culture (just like that), 4). The community has progressed and is so busy that they do not have time to watch traditional performing arts entertainment, and 5). People rarely want to respond to traditional performing arts because in general they have thought practically and economically [5]. Referring to the increasingly rapid influence of technology and also patterns of thought and the development of modern and advanced society, it is necessary to study and identify art. The role of various parties is able to revive the existence of jarogan art in Nganjuk Regency, because its existence has a meaning and regional image as a market for tourism economic development.

\section{LITERATURE REVIEW}

\section{Performance Art}

The subjective side is strongly influenced by various psychological factors, such as sensitivity, imagination, personal character, desire, and various experiences in particular. The objective side is influenced by environmental factors, such as the physical environment, value systems, the influence of tradition, social needs, material or material, cultural climate [6]. A spectacle that has artistic value where the spectacle is presented as a performance in front of an audience. Sal Murgiyanto also said that performance studies are a new discipline that brings together the arts (musicology, dance studies, theater studies) at one point of anthropology at another point in an interdisciplinary study (ethnomusicology, dance ethnology and performance studies) [7].

\section{Jaranan Pogogan}

Expression of pouring of observations and experiences related to feelings, physical and psychological activities in the form of work [8]. The results or work processes and human ideas that involve skilled, creative, sensory sensitivity, heart sensitivity and thought to produce works that have a beautiful, harmonious, artistic value, and others. In the creation / arrangement of a work of art carried out by the artists required creative skilled skills specifically according to the type of art they are making. Forms of art that exist today are quite diverse seen from the form of artistic creations, processes and techniques of work as well as the form of media that it uses [9].

\section{Branding Visit}

Branding is not always related to the brand name of a product or service from the company, but branding itself is not limited to product differentiation, but also related to trademarks, visual characteristics, credibility, perception, logo, image, impression, character and also the perception of consumers themselves over the product [10]. All efforts or programs are designed to increase value or avoid commoditization by building different brands [11].

\section{Content Analysis}

Content is an important element in implementing learning. Content acts as the core media of teaching and learning activities. Good content is able to combine explicit 


\section{Procedia Business and Financial Technology}

Proceedings of the 2nd International Conference on Business and M anagement of T echnology (ICO N BM T 2020) - Part 2

knowledge and tacit in the learning process as well as conventional learning. Explicit knowledge is knowledge that can be summarized in the form of documentation so that it is easily understood and disseminated. Tacit knowledge is knowledge contained in our brain or mind according to personal experience and is very difficult to communicate with others who have never experienced that knowledge before [12].

Applied media can be operationalized with the type of media used, frequency of use, and duration of use. There for it can be concluded that applied media can be measured with frequency, duration and intensity, so measuring applied beauty vlogger videos on YouTube can be described as follows:

1. frequency, is the number of behavioral repetition. Watching beauty vlogger videos on YouTube can take place in different frequencies, it can be every day, once a week or even once a month, depending on each individual. In this study measured by the number of times a person watches a beauty vlogger video on YouTube in a month.

2. Intensity, is the level of attention. Indicators for measuring the intensity of watching beauty vlogger videos on YouTube are internal factors that influence attention and external factors that attract attention. In this study measured by whether someone is paying attention to in detail all the ornaments that are on the beauty vlogger video on youtube [13].

\section{Tourism}

Is any person who travels to a country other than that in which she / he has his / her usual residence but outside his/her usual environment for a period not exceeding 12 months and whose main purpose of visit is other than the exercise of an activity remunerated from within the country visited [14].

Tourists are people who travel for the purpose of resting / vacationing, doing business, or for other trips such as medical treatment, religious visits and for study trips. By traveling and leaving their place of residence for a while, a person can be said to be a tourist. In addition, in his journey, one can be said to be a tourist. In addition, in the course of a tourist has a purpose, goals, such as resting, doing business and other purposes [15].

\section{METHOD}

The initial stage of this research is to conduct a survey, carried out by observing in the field of the preservation of traditional arts jaranan pogogan in Nganjuk District, then adding data variables to the preservation of traditional arts jarogan pogogan, after finding the location of the problem then a literature review is conducted, this is to determine the formulation of answers through literature study. Interview and literature study to identify what factors are behind the development of the traditional art of Pogogan network, followed by the creation of research instruments and data collection techniques and also by using data analysis, their use is to determine the answers to the problem formulation so that research findings emerge.

The main purpose of his research is to describe and analyze analytically about Teguh Rahayu's Pogogan terms in terms of the relationship between the verbal and non-verbal components of meaning from the Teguh Rahayu Pogogan's offerings and community responses. The connection with this research is how the network provides identity in verbal and non-verbal forms so that it can be used as a special image of the perpetrators of activities towards community implementation, but has not touched on its development related to traditional arts-based tourism, so this study is used as literature for the development of traditional arts specifically. At this stage of the research carried out starting with the determination of background, the purpose of this research is based on the formulation of the problem in determining research objectives based on the supporting factors of tourism development based on the arts of Pogogan network. This research is a content analysis, a research technique aimed at making conclusions by identifying certain characteristics in messages systematically and objectively [16] . Based on refresh procedure development. Explained ten-step implementation of research and development strategy as follows [17]:

1. Research and data collection (research an information collecting) which includes measurement of needs, study of literature, research on a small scale, and considerations in terms of value.

2. Planning (planning) that is compiling a research plan, covering the abilities needed in conducting research, the formulation of objectives to be achieved, with the research, design or research steps, and possibly within a limited scope.

3. Development of product draft (develop pleliminary form of product), development of learning materials, learning processes, and evaluation instruments.

4. Preliminary field testing. Field trials in one to three schools with six to twelve test subjects (teachers). During the trial, observations, interviews and distribution of questionnaires were conducted.

5. Revise the results of the trial (main product revision).

6. Main field testing. Conduct more extensive trials at 5 to 15 schools with 30 to 100 people testing subjects. Quantitative data on the teacher's previous performance and already using the model that was attempted was collected.

7. Improvement of product field test results (operational product revision).

8. Field implementation testing (operational field testing). 


\section{Procedia Business and Financial Technology}

Proceedings of the 2nd International Conference on Business and M anagement of T echnology (ICO N BM T 2020) - Part 2

Held in 10 to 30 schools involving 40 to 200 subjects. Testing is done through a questionnaire, interview, observation, and analysis of the results.

9. Refinement of the final product (final product revision).

10. Dissemination and implementation (disssemination and implementation).

\section{ANALYSIS DATA AND DISCUSSION}

\section{Data Analysis}

Content analysis is an in-depth study of the contents of written or printed information in the mass media, which pioneered the symbol coding technique, namely recording notes or messages systematically then interpreting [18]. The use of this analysis focuses on the overall form of communication as a whole. In the scope of publication in all media including newspapers, television, social media, advertising and also other media.

Table 1 Publication Data Variables

\begin{tabular}{|l|l|l|l|}
\hline No & Publication type & Variable & Percentage \\
\hline 1. & Social Media & 10 & $56,25 \%$ \\
\hline 2. & Opinion & 6 & $31,25 \%$ \\
\hline 3. & Letter & 2 & $6,25 \%$ \\
\hline 4. & Featured & 2 & $6,25 \%$ \\
\hline 5. & Article & 0 & $0 \%$ \\
\hline & Jumlah & 20 & $100 \%$ \\
\hline
\end{tabular}

In the process of publication through the media raises some publication content in support of distribution through the media. The distribution through the media is able to support the process of information data by the Nganjuk government which has a percentage of $56.25 \%$ obtained through social media data, then based on public opinion of $31.25 \%$, a balanced percentage obtained from letter data and also a number of $6.25 \%$ and in the form of articles is still around $0 \%$. Systematics and objectivity are obtained from messages and data at the time of observation and also analysis related to communication and information behavior that is carried out openly.

\section{Content Analysis}

To know the relativeity of the strength of the content in the content must have accuracy of data validation, the validity of the content indicates the extent to which questions, assignments or items in a test or instrument are able to represent the overall and proportional behavior of the sample subject to the treatment. This means that the instrument will reflect the entire content or material being tested or that should be controlled proportionally [19].

At least three types of communication research can be identified using content analysis. All three can be explained by the theory of the 5 elements of communication made [20]
, namely who, says what, to whom, in what channel, with what effect. The three types of research can contain one or more elements of questions. First, it is descriptive, namely the description of the contents of communication. In practice, this is easily done by comparison. The comparison can include the following things, namely:

1. Comparison of the same document message at different times. In this case the analysis can make conclusions about the tendency of the contents of communication.

2. Comparison of messages from the same source / single in different situations. In this case, the study of the effect of the situation on the content of communication.

3. Comparison of messages from the same source with different recipients. In this case, the study of the effect of audience characteristics on the content and style of communication.

4. Inter-message analysis, which is a comparison of the contents of communication at different times, situations or audiences. In this case, the study of the relationship of two variables in one or a set of documents (often called contingency).

5. Hypothesis testing regarding the comparison of messages from two different sources, namely differences between communicators.

Second, research on the causes of messages in the form of the influence of two messages produced by two sources (A and B) on behavioral variables that cause values, attitudes, motives, and problems at source B. Third, research on the effect of message A on recipients B. Questions that submitted is whether the effect or result of the communication process that hastaken place on the recipient.

\section{Content Analysis Method}

The basics of content analysis research design The basic procedures for making research designs and conducting content analysis studies consist of 6 steps, namely:

Research formulate questions and hypotheses, to do sampling of data sources that have been, The creation of categories used in the analysis, collecting a sample of documents that have been selected and encoding, Producing scale and items based on specific criteria for the collection of data, and ,Interpretation / interpretation of the data obtained. Technique manufacture of scale in content analysis had been described two kinds of techniques scaling (scaling), which aims specifically to measure the intensity. First, the Q-Sort method, provides a universe of scaling methods for statements about certain variables. The Q-Sort scale uses a 9 point scale distribution. In the first row, (Y) contains 9 points, which indicate the lowest level (1) to the highest level (9), and the second row (X) which shows the percentage of statements in each category. To determine which items belong to a certain category on an available scale, people who are considered judges are used. In this case the reliability of the measuringinstrument needs to be determined, and the validity 


\section{Procedia Business and Financial Technology}

Proceedings of the 2nd International Conference on Business and M anagement of T echnology (ICON BM T 2020) - Part 2

of the measurement.

The method of content validity analysis by 2 experts uses the formula in determining the correlation results of data validity as follows:

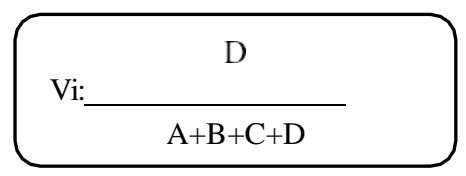

- $\quad$ Column D divided by $\mathrm{A}+\mathrm{B}+\mathrm{C}+\mathrm{D}$

- Cross tabulation table 2x2

\begin{tabular}{|l|c|c|c|}
\hline \multicolumn{2}{|c|}{ Cross Tabulation 2x2 } & \multicolumn{2}{c|}{ Rater I } \\
\cline { 3 - 4 } \multicolumn{2}{|c|}{ Rater II } & Less relevant score 1-2 & More relevant score3-4 \\
\cline { 2 - 4 } & More relevant score 3-4 & C & B \\
\hline
\end{tabular}

Information:

Vi: Construct validation

A: The second rater does not

B: rater I agreed, rater II disagreed

C: Rater I disagrees, rater II disagrees

D: Both raters agree
Content validity criteria:

$0.8-1$ : validity is very

high 0.6-0.79: high

validity

0,40-0,59: moderate validity

$0,20-0,39$ : low validity

$0,00-0,19$ : validity is very low
Results of assessment recap:

\begin{tabular}{|c|c|}
\hline Rater I & Rater II \\
\hline 3 & 3 \\
\hline 3 & 3 \\
\hline 3 & 3 \\
\hline 4 & 4 \\
\hline 4 & 4 \\
\hline 4 & 3 \\
\hline 4 & 4 \\
\hline
\end{tabular}

Based on the results of the assessment, in the form of a $2 \times 2$ cross tabulation as below:

\begin{tabular}{|l|l|l|l|}
\hline \multicolumn{2}{|l|}{ Cross Tabulation 2x2 } & Rater I \\
\cline { 3 - 4 } & $\begin{array}{l}\text { Less } \\
\text { relevant } \\
\text { score1-2 }\end{array}$ & $\begin{array}{l}\text { More } \\
\text { relevant } \\
\text { score3-4 }\end{array}$ \\
\hline Rater II & $\begin{array}{l}\text { Less } \\
\text { relevant } \\
\text { score 1-2 }\end{array}$ & A & B \\
\cline { 2 - 4 } & $\begin{array}{l}\text { More } \\
\text { relevant } \\
\text { score 3-4 }\end{array}$ & C & D \\
\hline
\end{tabular}

\begin{tabular}{|c|c|c|}
\hline Rater I & Rater II & Cross Tabulation \\
\hline 3 & 3 & D \\
\hline 3 & 3 & D \\
\hline 4 & 4 & D \\
\hline 4 & 4 & D \\
\hline 4 & 3 & D \\
\hline
\end{tabular}

Based on the results of the cross tabulation above, it is then entered into the formula:

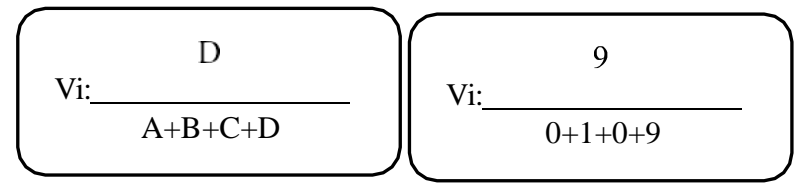

Conclusions from data based on validity criteria are very high.

\section{CONCLUSION}

Referring to the mapping analysis contained above and the results of the data-based discussion, it has several conclusions including:

1. With the implementation of brand visit based it is expected to be able to improve better branding, especially the development of traditional arts-based tourism in Nganjuk, East Java.

2. Optimizing the role of Jaranan Pogogan's traditional arts in the form of packaging that is more attractive, through the development of content in the form of social media modernization as a publication process without changing the original order of Jaranan art.

3. Optimization of international promotions so that the role of tourists is not only from domestic but also foreign tourists, so that with this achievement the traditional arts- based tourism sector is able to increase regionalincome.

4. The involvement of visitors as respondents to 


\section{Procedia Business and Financial Technology}

Proceedings of the 2nd International Conference on Business and M anagement of T echnology (ICO N BM T 2020) - Part 2

determine the actual data variables, so as to be able to track well the number of tourist visits, especially in Nganjuk Districtper year.

5. Attitude has a more significant influence on changes in equity in the value of visits. This implies that theeffectiveness of behavior is very influential on tourist visits in Nganjuk, East Java.

\section{SUGGESTION}

Based on the results of the study there are a number of suggestions given from researchers to related parties, as one of the bases, in an effort to increase tourism through Jaranan Pogogan art, including:

1. The process of updating data must be balanced with the use of data through the existence of new variables that are more relevant and simpler that appear in the research explanation. Because the implementation of the use of independent data variables have not been able to provide a detailed explanation of the level of accuracy of the data samples taken, which means that there is still a considerable influence on each variable.

2. The research method can also be added to the form of direct interviews to strengthen the questionnaire data, so that variations in the data will be obtained as well as more accurate than using a questionnaire alone.

\section{REFERENCES}

[1] Badan Pusat Statistik (BPS) Kabupaten Nganjuk. 2012.

[2] Alwasilah, A. Chaedar. 2006. Pokoknya Kualitatif. Jakarta. Dunia Pustaka Jaya Dengan Pusat Studi Sunda.

[3] Oka, A. Yoeti. 2008. Perencanaan dan Pengembangan Pariwisata. Jakarta. PT Pradaya Paramita.

[4] Kementerian Pariwisata. 2016. Laporan Kinerja Kementerian Pariwisata Tahun 2015. Jakarta: Kemenpar.

[5] Supratno, Haris. 1996. Wayang Sasak Laron Dewi Rengganis Dalam Konteks Perubahan Masyarakat Lombok, Kajian Sosiologi Kesenian. Surabaya: Universitas Airlangga. Disertasi.

[6] Gottschalk, Louis. 1986. Mengerti Sejarah (Diterjemahkan oleh Nugroho Notosusanto). Yayasan Penerbit UI: Jakarta.

[7] Murgiyanto. 1995. Ilmuseni.com. 2017.
Pengertian Seni Pertunjukkan Menurut Para Ahli Terlengkap.

[8] Read, Herbert. 1959. The Meaning Of Art. New York: Penguin Book.

[9] Sumanto. 2006. Pengembangan Kreatifitas Seni Rupa Anak TK. Jakarta: Direktorat Jendral Pendidikan Tinggi Direktorat Pendidikan Tenaga Kependidikan dan Tenaga Perguruan Tinggi.

[10] landa, Robin. 2006. Designing Brand Experiences. Thomson Delmar Learning.

[11] Neumeier, Marty. 2006. The Brand Gap. Berkeley: New Riders.

[12] Chimay, J. Anumba, Charles O. Egbu and Paticia Carrillo. 2005. Knowledge Management in Contruction. Blackwell Publishing Ltd.

[13] Kriyantono, Rachmat. 2009. Teknik Praktis Riset Komunikasi. Malang: Prenada Media Group.

[14] International Union of Official Travel Organization (IUOTO) and World Tourism Organization (WTO).

[15] Sugiama, A.G. 2011. Ecotourism: Pengembangan Pariwisata Berbasis Konservasi Alam. Bandung: Guardaya Intimarta.

[16] Abdul, Syukur Ibrahim. 2009. Metode Analisis Teks \& Wacana. Yogyakarta: Pustaka Pelajar.

[17] Borg \& Gall. 2003. Education Research. New York: Allyn and Bacon.

[18] Harold D, Lasswell. 2009. Structure An Function of Communication in Societ. Dalam Wilbur Schramm. (Ed).

[19] Gregory, R.J. 2000. Psychological Testing: History, Principles, and Aplications. Boston: Allyn \& Bacon.

[20] Harold D, Lasswell. 2009. Structure An Function of Communication in Societ. Dalam Wilbur Schramm. (Ed). 